\title{
Foreign Direct Investment and the Global Economic Crisis in the Western Balkan
}

\author{
Phd. Demir Lima
}

Europian University of Tirana

\author{
Doi:10.5901/ajis.2015.v4n2p473
}

\begin{abstract}
The primary purpose of investment is to increase employment and development services further. In general, Eastern Europe, instead of searching of a new model more convenient to growth, is constantly hiding behind the global economic crisis. Local crisis in Eastern Europe is still very important, but it is analyzed in the context of the global crisis, which is unacceptable. We need to see exactly what the global effects are, and what are effects of the local crisis. In general, all Eastern European countries have high public spending, inefficient administration, weak investment in research and development problems and serious problems regarding the quality of education. The global economic crisis has resulted only in further reduction of the gross domestic product (GDP), increasing the deficit, unemployment, lack of liquidity in the real sector throughout Eastern Europe.Western Balkan countries are in urgent need for a transition. Previous transition has pushed countries to much larger problems than they had before. Now it is necessary to create a serious strategy of economic and legal conditions favorable economic and investment in export-oriented sectors, aimed at long-term development of infrastructure, human resources and relatively high rates of economic growth.
\end{abstract}

Keywords: investment, crisis, transition, strategy, development.

\section{Introduction}

The key issue for the countries of Eastern Europe is the lack of strategy for attracting foreign direct investments.

They will not go beyond the first stage if it does not consider the economic viability of the investment, the real motives for the arrival of foreign investors and the origin of their capital. FDI will not be in order to increase the competitiveness of their companies, the international competitiveness of their products, increase employment and achieve better standard of living.

The largest green field investment is the mobile operator Promonte. Other Greenfield investments are usually associated with the services sector, such as the Hotel Splendid, the financial sector, such as Hypo Alpe Adria Bank and LB Leasing. Investments in production were weak, bottle factory Coca-Cola is an example which has invested $€$ $2,000,000$.

\section{An Overview of Foreign Direct Investment}

Promonte company is an example of the importance of an investment in the economy of a country. The Company was established in 1996 and marked the arrival of the first foreign investors in Montenegro, Greece - Norwegian consortium ETL (European Telecom Louxembourg), which consists of Telenor Mobile Communications AS com Investment, West and South Tel Topstar Shipping. Telenor is the leading telecommunications company in Norway and has major investments outside the country of origin, Hungary, Russia, Southeast Asia and Montenegro.

This was the first operator in Montenegro which began to write the history of mobile communications on 10 July 1996. Promonte has been a part of Telenor family from the first day, and since 11 August 2004 it has been owned $100 \%$ by Telenor. Headquartered in Norway, Telenor is the mobile operator in the world's seventh largest with nearly 150 million subscriptions in 12 mobile operators in Europe and Asia.

Telenor is emerging as one of the fastest growing providers of mobile communications services worldwide. Since the launch of GSM in 1996, Promonte is positioned as an operator with quality within the parameters required by focusing its products and services in the simplicity of tariff structure and courtesy to users. Promonte, has licenses of GSM, 3G and WiMAX technology, offers roaming, value added services and mobile data services over GPRS, EGDE-3G-HSDPA, WiMAX-WiFi to its subscribers with prepaid and postpaid.

Being among the most attractive employers in Montenegro, Promonte currently has nearly 300 employees, of whom more than half are university graduates. Of the total number of staff, $45 \%$ are women and they are equally 
represented in the management of the company. In Montenegro, the total FDI in 2008 amounted to 685 million euro and were little more than 2007 came to 678 million euro. However the structure of the flow, FDI had most of investments in real estate, which, according to the Central Bank of Montenegro, was also $51 \%$ or more than half of the 1 billion EUR in 2007. In 2008, almost $40 \%$ of FDI was invested in real estate, and $30 \%$ in companies and local banks, or debts between companies.

These data are of serious concern. Experience has shown that foreign direct investment in Montenegro have not increased production or have not introduced new products to market internationally competitive, but are mainly used for personal consumption. FDI in Montenegro are used for attractive purchases on the sea coast of Montenegro and other resources which are not directly in the creation of gross domestic product, and increase the efficiency of the local economy.

FDI should contribute to the development of enterprises and this is the best chance for long-term growth in production, employment, exports, increase the level of competitiveness and quality of life. FDI in Montenegro are in a function of consumption, which is an economic anomaly. The statistics for 2009 are slightly different. In the first two quarters of 2009, capital and financial account recorded an overstock of 290.9 million euro, which is much less than what was recorded in the comparative period of 2008 (698.4 million euro).

The net inflow of foreign direct investment in the first two quarters of 2009 amounted to 323.5 million euro, which is $1.1 \%$ more than in the same period of 2008. The total inflow of FDI in the reporting of FDI and the global economic crisis in Eastern Europe in this period amounted to 396.2 million euro. The structure of FDI changed significantly compared to previous years, when investments in real estate were widespread. Investing in local companies and banks has increased in the first half of this year, amounting to EUR 231.4 million or 38.9\% more than in the comparative period of 2008.

So 83.1 million euro (21\%) was in the form of debt between companies, and investments in real estate amounted to 81.4 million euro $(20.6 \%)$ or $52.5 \%$ less than in the comparative period. Most investments in the reporting period came from Italy, Great Britain and Austria. Next recapitalization of EPCG (Electric Power Company of Montenegro) and announced capital investments created real conditions for an influx of fresh capital and positive effects of economic diversification.

In structural terms, the situation in Serbia is similar. Serbian Privatization is almost complete, but the expected effect has failed to take shape, local companies have become very competitive in the international market and have started to create new jobs in the sector which should be export oriented. One can say that Serbia's economic structure is a consequence of the economic downturn in the late 20 th century privatization and economic policies from 2001 to 2008. Serbian Privatization is implemented in the following way: companies are often sold to the owners of suspected capital.

FDI through privatization has meant selling the property. Owners use the assets to maximize short-term goals and not to boost employment and long term economic activity. New jobs are created mainly in sectors that are able to export (financial intermediation, trade, real estate, rental services). The model of development in Serbia is mainly based on banks, shopping centers, bookies and building luxury housing and business facilities. In this way Serbia can't build an important export industry capable of supporting the economy.

If you look at the structure of gross value added (gross domestic product without taxes and subsidies) for 2009, $60 \%$ of GDP comes from services, and only $29 \%$ from industry and construction.

Albania has the same approach in attracting foreign direct investment, although the data show that foreign direct investment increased in 2009. In the first nine months of 2009, Albania has drawn 565 million euro of foreign direct investment, which is 214 million more than in the same period of 2008. the structure of foreign direct investment in Croatia is still dominated by investments in financial intermediation. The largest amount of total direct investments came from Austria (325 million euro), and since 1993 investments worth 6.1 billion euro have been poured from Austria to Croatia, which is a third of the total investment.

Balance of payments deficit in Croatia in 2009 will be covered by FDI and their further decline in 2009 was among other things due to the global economic crisis. It is clear that all these countries have the same problem. They do not use foreign direct investment projects or export production. In this way, the crisis in which Eastern Europe has been for a long time even further deepens. Another structural problem of Eastern Europe is the following one: a model of economic growth of all countries is based exclusively on FDI, which is a very big mistake.

If they are dependent only on FDI and not thinking about the production, export competitiveness and a better quality of life they are forced to become a loser in the long term.

FDI should be a permanent value, and not the parameter in which economic growth model is based currently. Regarding industrial production Montenegro has seen a significant decrease of $32.2 \%$. Furthermore, Montenegro is faced with the problem of undeveloped industrial processing. On the other hand, Montenegro has a highly developed sector of 
services, which is the result of the final expenses arising from foreign direct investment.

The service sector should be consistent with the manufacturing sector in any economy. For example, the timber industry, which has the potential export, the most important items of export are treated simply as raw wood or wood. This product export of Montenegro has a low degree of processing, low added value and is often based on insufficient productive use of existing natural resources.

The main export product in Montenegro is aluminum. In some sectors, especially in the production and processing of metals should not expect dramatic failures. In the case of a small economy like Montenegro, the bankruptcy of a big company like (Aluminium Smeltery) can have catastrophic consequences. (Aluminium Smeltery) (KAP) was sold to Russian CEAC (Central European Aluminium Company) and KAP accounts for 40\% of GDP.

In the case of Serbia the global crisis has hampered a part of capital inflows from abroad. This showed that Serbia has no economic structure capable of productive employment of citizens, to convert debts and maintain macroeconomic stability. Despite the development of the Serbian economy 2001-2008, Serbian industrial production is reduced about $50 \%$ compared to 1990 . For example, the total value of construction work performed by container workers first quarter of 2009 , compared with the same period last year, decreased by $11 \%$ at current prices, and $17 \%$ at constant prices.

The value of contracts in the first quarter of 2009 compared to 2008 at current prices decreased by $45.5 \%$ and the number of building permits issued decreased by $16.7 \%$. Moreover, what will happen when Montenegro (and elsewhere) will privatize all state enterprises and implement FDI through privatization? On what basis will build its own model of economic growth?

The privatization process has been initiated, with restructuring programs approved for the following companies: "Zeljeznice Crne Gore", "Montenegro Airlines" and "Posta Crne Gore". Preparation and implementation of public procedures for selection of investors for implementation of projects related to the assessment exclusive tourist locations: "Ada Bojana", "Velika Plaza", "Njivice", "Utjeha", "Buljarica" and "Jaz". Montenegro expects a lot from building the highway Bar-Boljari, because investment should undertake more activities.

It remains an open question how it will help long-term investment in Montenegro, which does not have a building industry well developed, metal industry or wood industry.

We should hope that these investments will increase employment and development services further. In general, Eastern Europe, instead of looking for a new model, more convenient to growth, is constantly hiding behind the global economic crisis. Local crisis in Eastern Europe is still very important, but it is analyzed in the context of the global crisis, which is unacceptable.

We need to see exactly what the global effects, and what are the local effects of the crisis. In general, all Eastern European countries have high public spending, inefficient administration, poor investments in the areas of research and development and serious problems regarding the quality of education.

The global economic crisis has resulted only in further reduction of the gross domestic product (GDP), increasing the deficit, unemployment, lack of liquidity in the real sector throughout Eastern Europe. The most dramatic example is Croatia, which has been the problem of external debt for years. In 2009 the Croatian GDP amounted to around 39 billion euro. Foreign debt at the end of 2008 amounted to 39.1 billion euro, and for the first time in history was greater than the annual GDP.

Western Balkan countries are in urgent need for a transition. Previous transition has pushed them to the larger problems than what they had before. Now it is necessary to create a serious strategy of economic and legal conditions favorable economic and investment in export-oriented sectors, aimed at long-term development of infrastructure, human resources and relatively high rates of economic growth.

At the end of 2009 the share of foreign direct investment (FDI) to the gross domestic product (GDP) in Albania has been the highest in the region (8.1\%), followed by Croatia (4.61\%), Serbia (4.5\%), Macedonia (2.7\%) and Bosnia and Herzegovina (1.4\%). Note that the expansion in FDI during the last three years in Albania associated with a decline of FDI to other countries in the region. During this period the calculation to take into consideration is the maximum value of FDI to GDP has reached Serbia in 2006 (17\%) and this country has reached the minimum value of FDI to GDP in 2000 $(0.85 \%)$.

Foreign direct investments are one of the most important indicators and important enough to show the value of foreign investor confidence towards the host country and are towards the reduction ratio in terms of economic and political crises and grow in terms of improving the economic and political environment.

Macedonia has 5 times less investment than Albania. Investments in Macedonia are reduced and even in future years can't be warned any economic growth but is expected to have the trend of falling. This conclusion is taken by economic experts based in the country's disinterest to attract foreign investors over although the country has a large 
number of industrial zones.

According to them foreign direct investment in the country and around are based on 'improving the business environment, the establishment of security in the state and the privatization of large companies that were owned by the state' '. The data show that investments in Macedonia counted as the poorest in comparison with regional countries because in 2009 in Macedonia are invested only 181 million euro, in Albania are invested about 565 million euro and at the same year in Kosovo are investing 310 million euro.

In Albania during 2009 Foreign Direct Investment (FDI) increased by $45 \%$ compared to 2008, but only in the first half of 2009 in Albania are invested 565 million euro from 351 million euro that were a year ago. Even in Kosovo, the situation is much better than in Macedonia since the investments in 2009 were about 310 million euro although a year ago were $30 \%$ higher which means about 355 million euro.

We left behind the 2013 a year with several economic problems. For the purpose of this paper will address the situation of foreign direct investment in the countries of Eastern Europe. Eastern European countries were not only affected by various political crises, economic and social but also share their important instruments other common features of transition economies such as the level and pace of development and distortion of the market economy. Economic conditions that are hindering Europe now again are restricting economic activity and government revenues in these countries.

Southeast European countries reached an economic growth of 2.2 million euro in 2011. According to ongoing economic analysis indicators show that economic growth in these countries has slowed drastically, was received very little growth in the coming years. In Regular Economic Report of the World Bank's Southeast Europe, was confirmed that the economy of Eastern Europe began to recover from the recession of 2012 being increased on average 2.2\% in 2013. The report also said future prospects, saying that economy will grow by $1.9 \%$ in 2014 and $2.6 \%$ in 2015 thanks to increased foreign demand. Recent floods that occurred in the region lessened some extent hopes for economic growth.

Floods that occurred in Bosnia and Serbia because of rainfall in May 2014, the humanitarian crisis caused dozens of deaths. Obviously this situation caused casualties and economic damage of the pace of economic growth. In 2013, each of the countries of Eastern Europe recorded positive growth. Growing at 3 percent or more were recorded in Kosovo, the former Yugoslav Republic of Macedonia and Montenegro.A good year for agriculture and industry growth supported economic activity in the region in all states.

\begin{tabular}{|ccccc|}
\hline \multicolumn{6}{|c|}{ Eastern Europe: Real GDP growth in percentage } \\
\hline Albania & 2012 & 2013 & 2014 & 2015 \\
\hline Bosnia & 1.3 & 0.4 & 2.1 & 3.3 \\
Kosovo & -1.1 & 1.8 & 2 & 3.5 \\
Macedonia & 2.7 & 3 & 3.5 & 3.5 \\
Montenegro & 0.4 & 3.1 & 3 & 3.5 \\
Serbia & -2.5 & 3.5 & 3.2 & 3.5 \\
EJG6 & -1.7 & 2.5 & 1 & 1.5 \\
\hline
\end{tabular}

Note: Weighted average of GDP.2013 is rough estimate. 2014 and 2015 are World Bank staff projections.

\section{Source: World Bank}

Eastern European countries find themselves faced with some facts public debt level too high, funding pressures, both these facts lead to one direction, Europe should adopt broad programs of fiscal consolidation to change the situation with debts. Other factors affecting the economic level of these countries are Greece's economic crisis. Of course this kind of crisis will make the authorities to require banks to increase their reserves and to make the sector more resistant.

In 2013, Eastern Europe began to recover from the recession, "Economic growth was made possible thanks to the growing demand for regional exports from countries with high income, especially from the countries of the European Union (EU).

According to the report, exports increased by nearly 17 percent in 2013 led by a rapid increase in Serbian exports. The main growth in 2013 came from the export of machinery and transport equipment, mainly from Serbia and Macedonia. Meanwhile combustible minerals exported from Albania and Montenegro were more significant for these two countries, while base metals took about a quarter of exports from Kosovo in 2013. 
In contrast, domestic demand in the region shrank in 2013. Another problem in this regard is that unemployment and poverty are higher in Eastern Europe than in any other European country. Domestic demand has been more under pressure from reduced remittances to the region in 2013, reflecting a still sluggish economic recovery and high unemployment predominantly in EU countries.

With few jobs open, reduction of remittances and limited credit in the economy, household income and profits of companies were not able to promote domestic consumption and investment in the region. "In general, while the recovery has brought growth, countries in the region have limited access to the translation of economic recovery in jobs," "Unemployment has been very high in the region, with an average level of over 24 percent in 2013.

\section{Conclusion}

Continuing high levels of unemployment and chronic unemployment prevailed among vulnerable groups, such as youth, women, and people with low skills. "According to the report, the challenges are still present and require action on financial and fiscal sectors. Mitigation of bad loans high and growing, the resumption of credit growth for businesses borrowing, consolidation effort determination to maintain fiscal balance and public debt reduction would lead to acceleration of economic activity. To support growth in the region, countries should further strength the foundations of macro-economic internal to help increase production and resistance to external disturbances.

Moreover, the economic recovery recently is an opportunity to re launch structural reforms long needed. The advantages for growth and creation of new work places include macro-economic and fiscal stabilization, improving competitiveness and connectivity, increase skills and labor productivity, and strengthen governance and anticorruption.

Together with the recovery, it is time that attention should be focused on creating an investment climate stimulating growth in exports and connectivity support.

\section{References}

Economist Annual Report 2009127

Ellen Goldstein, World Bank Director for South Eastern Europe.

Investment Promotion Agency of Montenegro Statistics 2009

Progress Report on Montenegro 2008.

Report of Croatian National Bank 2009.

Serbia Annual Statistical Report 2008: 134.

Slavica Penev, Matija Rojevc - "Foreing Direct Investment and the Investment Climate in South- East Europe", Belgarde, September 25,2009

The Central Bureau of Statistics 2009.

World Investment Report 2009c: 75. 
